\title{
ПЕРСПЕКТИВА ПІДГОТОВКИ ЛІКАРІВ У ТЕРНОПІЛЬСЬКОМУ ДЕРЖАВНОМУ МЕДИЧНОМУ УНІВЕРСИТЕТІ ІМЕНІ \\ І. Я. ГОРБАЧЕВСЬКОГО
}

\author{
І. Р. Мисула, А. Г. Шульгай, К. О. Пашко, І. М. Кліш \\ ДВНЗ “Тернопільський держсавний медичний університет імені І. Я. Горбачевського МОЗ Украӥни”
}

\section{THE PERSPECTIVE OF DOCTORS' TRAINING IN TERNOPIL STATE MEDICAL UNIVERSITY BY I. YA. HORBACHEVSKY}

\author{
I. R. Mysula, A. H. Shulhay, K. O. Pashko, I. M. Klishch \\ SHEI "Ternopil State Medical University by I. Ya. Horbachevsky of MPH of Ukraine"
}

\begin{abstract}
У статті подано короткий історичний екскурс становлення медичного факультету Тернопільського державного медичного університету імені І. Я. Горбачевського. Показані перспективи розвитку факультету згідно з концепцісю розвитку Тернопільського державного медичного університету.
\end{abstract}

The article presents the short historical excursus of formation of the medical faculty of Ternopil State Medical University by I. Ya. Horbachevsky. There are shown the prospects of faculty development taking into consideration the concept of development of Ternopil State Medical University.

Вступ. Медичний факультет заснований 12 квітня 1957 року, на той час він був першим і єдиним факультетом Тернопільського державного медичного інституту.

I сьогодні це найбільший факультет Тернопільського державного медичного університету. На 30 кафедрах медичного факультету працює 410 викладачів, в тому числі 71 доктор наук, 63 професори, 156 доцентів, 262 кандидати наук. Серед викладачів: 3 члени-кореспонденти Академії медичних наук України, 9 заслужених діячів науки і техніки України, 3 заслужені винахідники України, 4 заслужені лікарі України. 32005 року студенти факультету навчаються за кредитно-модульною системою, що стало передумовою конвертування диплома нашого ВМH3 у всіх країнах Свросоюзу. Згідно з Концепцією розвитку ТДМУ імені І. Я. Горбачевського (2006 р.) на факультеті запроваджено навчання за методикою “єдиного дня" та Z-система навчання, завдяки останній, вже на молодших курсах, при вивченні теоретичних дисциплін, студент знайомиться з їх прикладними клінічними аспектами, вчиться працювати на апаратурі, освоює методи дослідження, з якими він пізніше зустрінеться у клініці. На факультеті запроваджено дистанційний контроль знань в системі Moodle. 3 2006 р. студенти почали складати семестрові комплексні тестові іспити та об’єктивні структуровані клінічні іспити. Для організації самостійної роботи студентів на Web-порталах усіх кафедр розміщені навчальні матеріали, доступ до яких має кожен студент. Враховуючи, що на кафедрах ННІ навчаються i іноземні студенти, всі робочі навчальні програми та додаткове методичне забезпечення розроблені крім української також англійською і російською мовами у вигляді матеріалів для підготовки до практичних занять, презентацій лекцій, методичних вказівок для студентів, алгоритмів практичних навичок, методичних розробок для викладачів. Вони створені в паперовому та в електронному варіантах, тому студенти мають до них вільний доступ через інтранет-мережу круглодобово.

16 теоретичних кафедр медичного факультету об'єднані у чотири навчально-наукових інститути, які $є$ структурними підрозділами факультету: ННІ морфологіi, ННІ фармакологіi, гігієни та медичної біохіміі ім. М. П. Скакуна, ННІ медико-біологічних проблем, ННІ моделювання та аналізу патологічних процесів. Вони створені з метою підготовки сучасних спеціалістів, які повинні в достатній мірі володіти медичними знаннями і навичками, а також для проведення наукових досліджень за профілем інституту.

Після об'єднання клінічних кафедр їх загальна кількість на факультеті становить 14. Подібне укрупнення підрозділів дозволило привести їх у 
відповідність до тих, які є у Свропейському Союзі, та оптимально використовувати наявні матеріальнотехнічні ресурси. Це створило сприятливі умови для вдосконалення навчально-методичного та наукового процесів у ННІ та на кафедрах університету.

На факультеті функціонує 13 комп'ютерних класів та читальних залів. Всі комп'ютери під'єднані до мережі Інтернет, співвідношення комп'ютерів до студентів склало - 1:4. 3 метою поліпшення доступу студентів до навчальної літератури проводиться переведення книг бібліотеки в електронні підручники, у т. ч. і англомовні. Оновлені і перенесені на компакт-диски 267 навчальних фільмів.

Ряд авторських колективів викладачів факультету випустили у світ навчальні підручники та посібники, які розійшлися по всіх ВМ(Ф)НЗ України $1-4$ рівнів акредитації.

Лікувально-консультативну роботу фахівці факультету проводять у базових відділеннях лікарень та поліклінік. Крім цього, ними в клінічну практику щорічно впроваджуються десятки нових діагностичних та лікувальних методик, що покращує рівень надання спеціалізованої медичної допомоги населенню області.

На факультеті, де навчається понад 1,5 тисячі студентів, створюються всі необхідні умови для досягнення основної мети - підготовки висококваліфікованого лікаря. Навчальні групи формуються з 10-12 студентів, а на VI курсі - 3 7-8 студентів, що дає можливість індивідуалізувати навчальний процес. Для читання лекцій обладнано 10 лекційних аудиторій з сучасною демонстраційною апаратурою. Практичні та семінарські заняття зі студентами проводяться в навчальних лабораторних і тематичних кімнатах, а клінічні - біля ліжка хворого і в кабінетах функціональної, лабораторної та інструментальної діагностики.

Основна частина. На факультеті завдяки допомозі керівництва університету на чолі з ректором чл.кор. НАМН, проф. Л. Я. Ковальчуком постійно йде оновлення навчальної матеріально-технічної бази, ремонт приміщень, придбання нової сучасної апаратури та приладів. Прикладом може служити НHI медико-біологічних проблем, де проведено капітальний ремонт більшої частини приміщень. Показовим $\epsilon$ впровадження Z-системи у навчальний процес на кафедрі нормальної фізіологіі, де для проведення практичних занять за цикловим методом обладнано шість тематичних навчальних лабораторій. У лабораторії нейрогуморальної регуляції функцій організму виконуються дослідження функцій кори головного мозку з використанням цифрового комп'ютерного електроенцефалографічного комплексу DX-NT, вітчизняного виробництва. У лабораторії системи крові для проведення практичних занять використовуються бінокулярні мікроскопи GRANUM L-20, обладнані системою підсвічування. Дана лабораторія також оснащена рН-метрами, фотоелектрокалориметрами, центрифугами, апаратами Панченкова, камерами Горяєва, що дозволяє кожному студенту визначати показники гематокриту, гемоглобіну, швидкості осідання еритроцитів, рН плазми і крові, підраховувати кількість клітин та формених елементів крові.
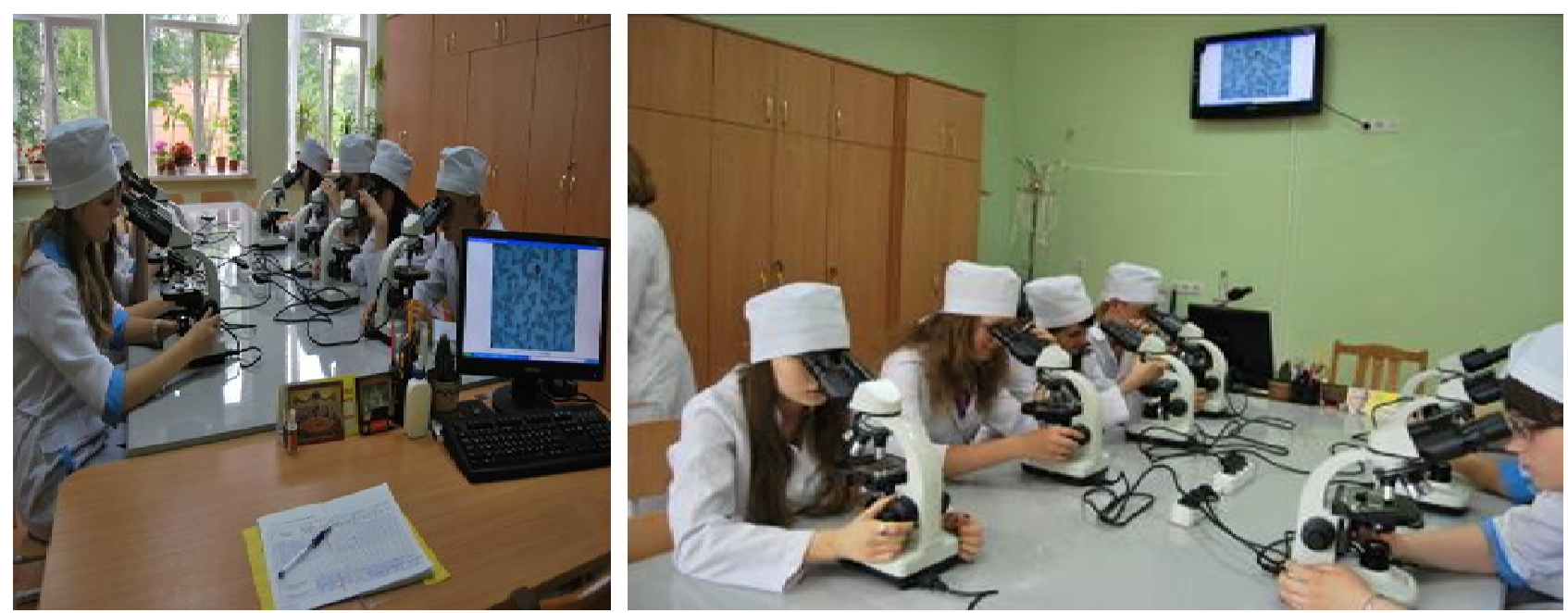

Студенти проводять аналізи крові у лабораторії функціональної діагностики системи крові

Лабораторія функціональної діагностики системи кровообігу забезпечена трьома електрокардіографами “Юкард-200", які крім реєстрації електрокардіограм дозволяють передавати ЕКГ у діагностич- ний центр обласної лікарні з використанням GSMканалу зв'язку, та двома комп'ютерними електрокардіографічними комплексами з програмою “Поліспектр+". 

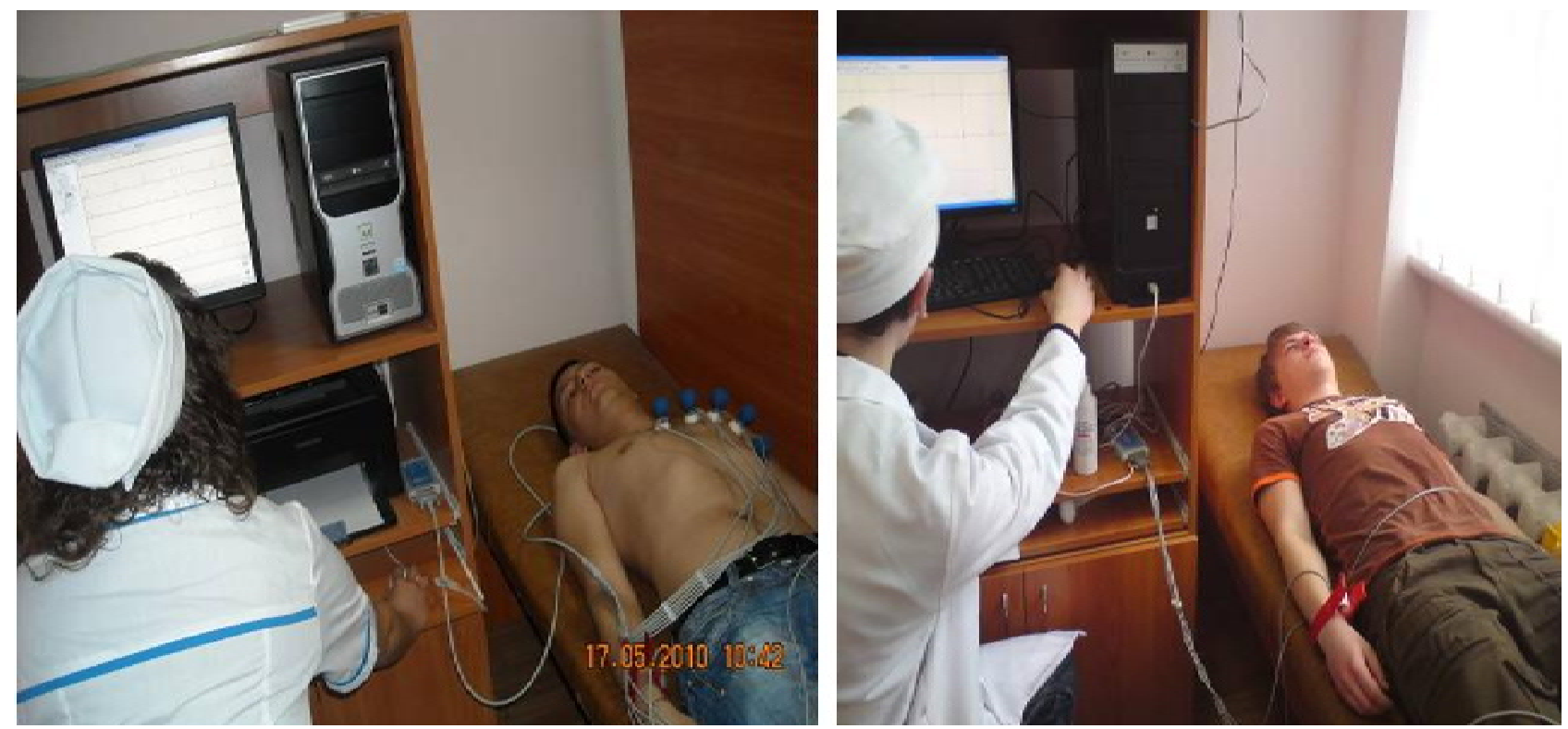

\section{Проведення електрокардіографії у лабораторії функціональної діагностики системи кровообігу}

Для вивчення механізмів регуляції діяльності серця студентами на практичних заняттях використовуються комп'ютерні комплекси для проведення математичного аналізу серцевого ритму. Оцінка стану центральної та периферичної гемодинаміки проводиться за допомогою комп'ютерного реографіч- ного комплексу “Реоком”. Лабораторія функціональної діагностики системи дихання забезпечена 4 сучасними цифровими спірографами СМП 21/01 Р-Д, які дозволяють отримувати та оцінювати великий об'єм функціональних показників дихальної системи.
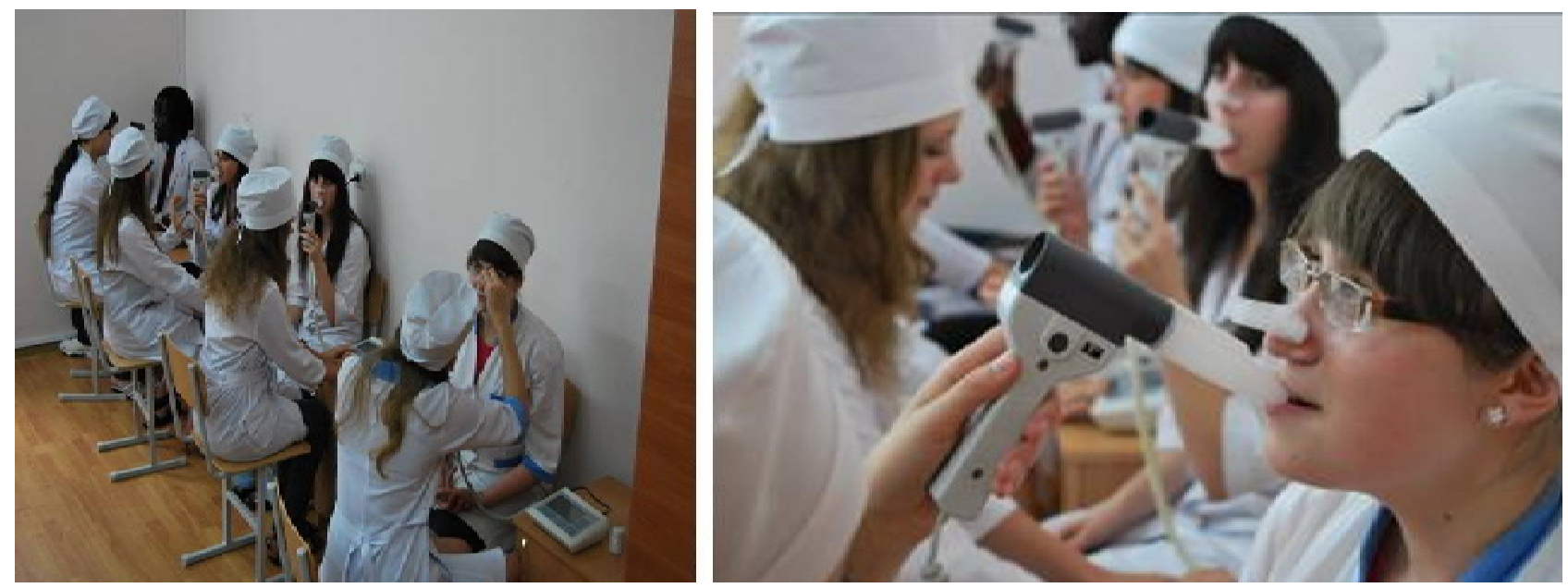

Проведення дихальних проб у лабораторії функціональної діагностики системи дихання

Лабораторія функціональної діагностики системи травлення оснащена сучасними цифровими $\mathrm{pH}-м е т-$ рами ИКЖ-2 та фантомами, що дає можливість проводити студентам рН-метрію шлунка, модулюючи показники кислотності, і вивчати механізми регуляції кислотопродукуючої функції шлунка. У лабораторії функціональної діагностики сенсорних систем у навчальному процесі використовується авторефрактометр/кераторефрактометр URK -700, за допомогою якого проводиться оцінка стану рогівки і оптичних середовищ ока. Для визначення полів зору викорис- товується комп'ютерний аналізатор поля зору “Перитест-300". Для вимірювання внутрішньоочного тиску застосовується безконтактний цифровий індикатор ИГД - 02 "ПРА". Також студенти мають можливість вивчати стан очного дна за допомогою офтальмоскопів. Для засвоєння навиків проведення корекції міопії та гіперметропії використовується набір, який складається із 158 пробних окулярних лінз для корекції зору. Для оцінки функції слухової сенсорної системи на практичних заняттях, крім аналогових аудіотестерів, застосовується сучасний ультразвуко- 
вий ехотестер. Стан вестибулярного аналізатора вивчається за допомогою функціональних проб з використанням крісла Барані. Також ця лабораторія оснащена засобами та комп'ютерними програмами для проведення психофізіологічної діагностики.

За кожною тематичною лабораторією закріплений викладач, який пройшов курси з оволодіння навиками роботи з сучасною апаратурою в навчальних закладах та клінічних базах і отримав сертифікат. Завдяки спеціалізації кожен викладач має більше можливостей щодо постійного підвищення рівня своїх знань за рахунок ознайомлення 3 новинками української та зарубіжної науки з даного розділу і швидкого запровадження їх у навчальний процес. Така організація навчального процесу дозволяє більш ефективно використовувати обладнання, сприяє його збереженню та правильному обслуговуванню.

Кожна навчальна кімната оснащена відеосистемами з LCD-моніторами, комп'ютерами, які підключені до мережі Internet, що дає можливість використовувати у навчальному процесі відеофільми із методиками проведення досліджень, анімаційні моделі та таблиці.

Всього за останніх 5 років тільки на кафедру фізіології закуплено обладнання на суму 520 тисяч гривень.

Проведено капітальний ремонт ряду приміщень, а також заміну покриття даху в ННІ морфології. Під час проведення практичних занять в інституті ефективно використовують відеосистеми.

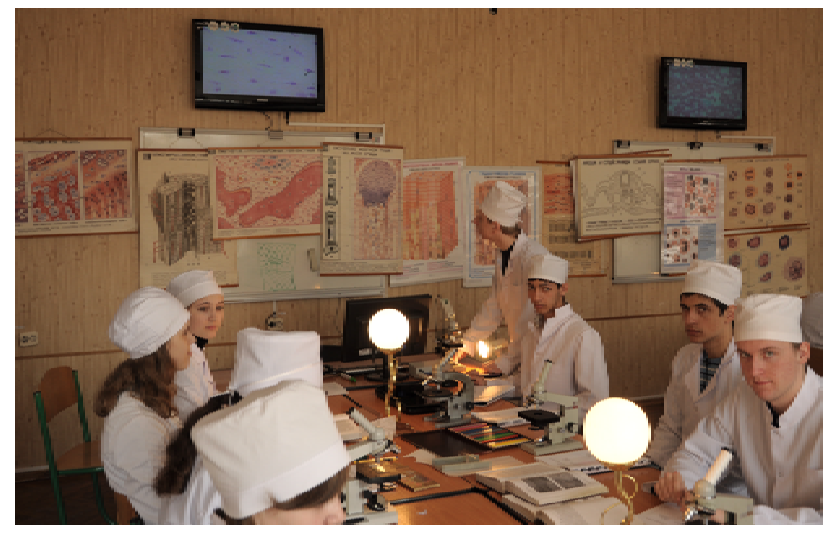

\section{Використання відеосистем на кафедрі гістології}

Почато капітальний ремонт приміщень лівого крила корпусу, у якому розміщено ННІ фармакології, гігієни та медичної біохімії ім. М. П. Скакуна, із заміною вікон, дверей, підлоги, перил, освітлення, установленням підвісних стель, ремонтом стін, у ньому теж планується заміна покриття даху. Уже обладнується бібіліотека і новий комп'ютерний клас НHI, який буде укомплектований новими комп’ютерами.
У всіх навчальних кімнатах будуть установлені на кожну групу окремо сучасні відеосистеми та виготовлені у мебельному цеху університету нові меблі. Треба відмітити, що сучасні відеосистеми планується придбати у навчальні кімнати усіх ННІ. На придбання комп'ютерів і відеосистем уже оголошені конкурсні торги. Проводиться капітальний ремонт і обладнання лекційної аудиторії на 48 місць у бувшому приміщенні ЦМК з заміною підлоги, освітлення, установленням підвісної стелі, ремонтом стін, умеблюванням, установкою комп'ютера, підвісного відеопроектора, підведенням Інтернет-мережі.

\section{У 2012-2013 н. р. планується:}

- провести капітальний ремонт і обладнати роздягальні у напівпідвальних приміщеннях корпусів ННІ фармакології, гігієни та медичної біохімії ім. М. П. Скакуна, ННІ медико-біологічних проблем, що поліпшить побут студентів;

- провести капітальний ремонт і обладнати лекційні аудиторії № 1 та № 9 (відповідно у корпусах ННІ фармакології, гігієни та медичної біохімії ім. М. П. Скакуна і ННІ моделювання та аналізу патологічних процесів) із заміною підлоги, освітлення, установленням підвісної стелі, ремонтом стін, умеблюванням, установкою комп'ютера, підвісного відеопроектора, підведенням Інтернет-мережі;

- провести капітальний ремонт правого крила корпусу ННІ фармакології, гігієни та медичної біохімії ім. М. П. Скакуна, у т. ч. кафедри загальної гігієни та екології із заміною вікон, дверей, підлоги, перил, освітлення, ремонтом стін, обладнанням підвісної стелі та освітлення та закінчити проведення капітального ремонту кафедри медичної біохімії із заміною вікон, підлоги, обладнанням підвісної стелі та освітлення, частковим облицюванням плиткою стін навчальних класів;

- подати заявки на придбання у 2012-2014 рр. нової сучасної навчальної апаратури і приладів для кафедр усіх інститутів.

Після проведення капітального ремонту у трьох указаних вище ННІ заплановано у 2014 р. провести капітальний ремонт і у ННІ моделювання та аналізу патологічних процесів 3 монтуванням підвісних стель, заміною освітлення, підлоги, вікон тощо.

Перспективи організації навчальної роботи на факультеті.

Враховуючи позитивний досвід кафедри фізіології з 2012 року під час вивчення дисциплін на кафедрах факультету передбачати розподіл їх на цикли, які мають відповідати змістовим модулям робочих програм навчання для медичного факультету. Одного- 
двох викладачів протягом навчального року закріпляти за кожним циклом з одного модуля. Ці викладачі повинні глибоко вивчити сучасні методи дослідження зі свого циклу з використанням усіх інформаційних ресурсів. За такої організації навчального процесу викладач набуває достатнього досвіду та досягає глибокого професіоналізму за напрямом вибраного циклу, а кожна група студентів отримує можливість познайомитися із більшістю викладачів кафедри, також це сприятиме більш об'єктивному оцінюванню студентів. 3 цією метою протягом 2012-2017 років забезпечити навчальний процес достатньою кількістю сучасних приладів, манекенів та фантомів, потрібних для засвоєння кожної теми, і укомплектувати ними тематичні класи кафедр відповідно до визначених циклів.

Спрямовувати діяльність студента під час опрацювання практичної частини заняття тільки на ті види роботи, які мають пряме відношення до фахової підготовки, з використанням достатньої кількості сучасних приладів, манекенів, фантомів, сучасних анатомічних муляжів і пластинатів та інших засобів, потрібних для засвоєння кожної теми.

Ввести в практику під час семінарської частини заняття, крім традиційного варіанта обговорення навчального матеріалу, заслуховування і обговорення оглядових доповідей з опрацювання 20-30 літературних джерел за останні три роки. За змістовні доповіді при цьому підвищувати оцінки до 11-12 балів та рекомендувати найбільш повні та цікаві до публікації у вигляді наукової статті в періодичних виданнях.

Постійно поповнювати базу тестових завдань, урізноманітнювати ії ситуаційними задачами та графічними зображеннями. Довести кількість тестових завдань на одне практичне заняття до 2017 р. до 285 на одне заняття.

Створити протягом 2012-2013 років теку тематичних навчальних відеофільмів трьома мовами - українською, російською та англійською 3 кожного змістовного модуля для навчальних тематичних кімнат, обладнаних відеосистемами.

Професорсько-викладацькому складу факультету активно провдовжувати роботу з написання нових підручників, посібників, атласів, удосконалювати різноманітні методичні матеріали і своєчасно розміщати їх на Веб-сторінках кафедр.

Викладацькому складу факультету вдосконалювати рівень володіння англійською мовою, направляти молодих перспективних викладачів на курси оволодіння нею з подальшою сертифікацією.
Започаткувати у 2015 р. телекомунікаційні лекції на кафедрі соціальної медицини для студентів 5 курсу (спеціальність “Лікувальна справа”) провідних фахівців із організації охорони здоров’я України.

Перспективи розвитку наукової роботи на факультеті.

Починаючи з 2012 р. підвищити ефективність наукових досліджень шляхом впровадження інноваційних пропозицій (заявки на винахіді декларацію, рацпропозицію). Для покращення інноваційної та патентної роботи доцільно поєднувати зусилля декількох кафедр під час виконання планової наукової роботи. Організувати співпрацю з інститутами і лабораторіями Національної академії медичних наук України та іншими науковими і вищими медичними навчальними закладами. Сконцентрувати основних наукових працівників і матеріальні ресурси за кількома пріоритетними науковими напрямками. Активізувати пошук міжнародних грантів на проведення наукових досліджень і участь у державних наукових програмах.

Створювати сприятливі умови для своєчасної підготовки та захисту кандидатських і докторських дисертацій відповідно до планових термінів.

Перспективи розвитку лікувальної роботи на факультеті.

Активно впроваджувати в лікувальний процес результати дисертаційних робіт, виконаних на клінічних кафедрах, а також результати нових методів лікування, затверджених в Україні.

Забезпечити проходження до 2017 р. спеціалізації 100 \% викладачів, які працюють в спеціалізованих відділеннях 3 профільних спеціальностей, а також забезпечити кожні 5 років проходження курсів підвищення кваліфікації $з$ профільних спеціальностей кожного з викладачів, які працюють в спеціалізованих відділеннях.

Кожній клінічній кафедрі організовувати та проводити не рідше одного разу за 3 роки науково-практичної конференції, семінару спільно з лікарськими товариствами і профільними асоціаціями лікарів.

Висновок. Медичний факультет є найбільш потужним підрозділом університету і з допомогою керівництва університету, очолюваного ректором чл.- кор. НАМН проф. Л. Я. Ковальчуком, створив та продовжує зміцнювати свою навчально-матеріальну базу, яка відповідає вимогам щодо підготовки сучасного фахівця європейського і світового рівнів. Професорсько-викладацький склад розуміє і виконує поставлені перед ним завдання та впевнено йде до 60-річчя університету. 